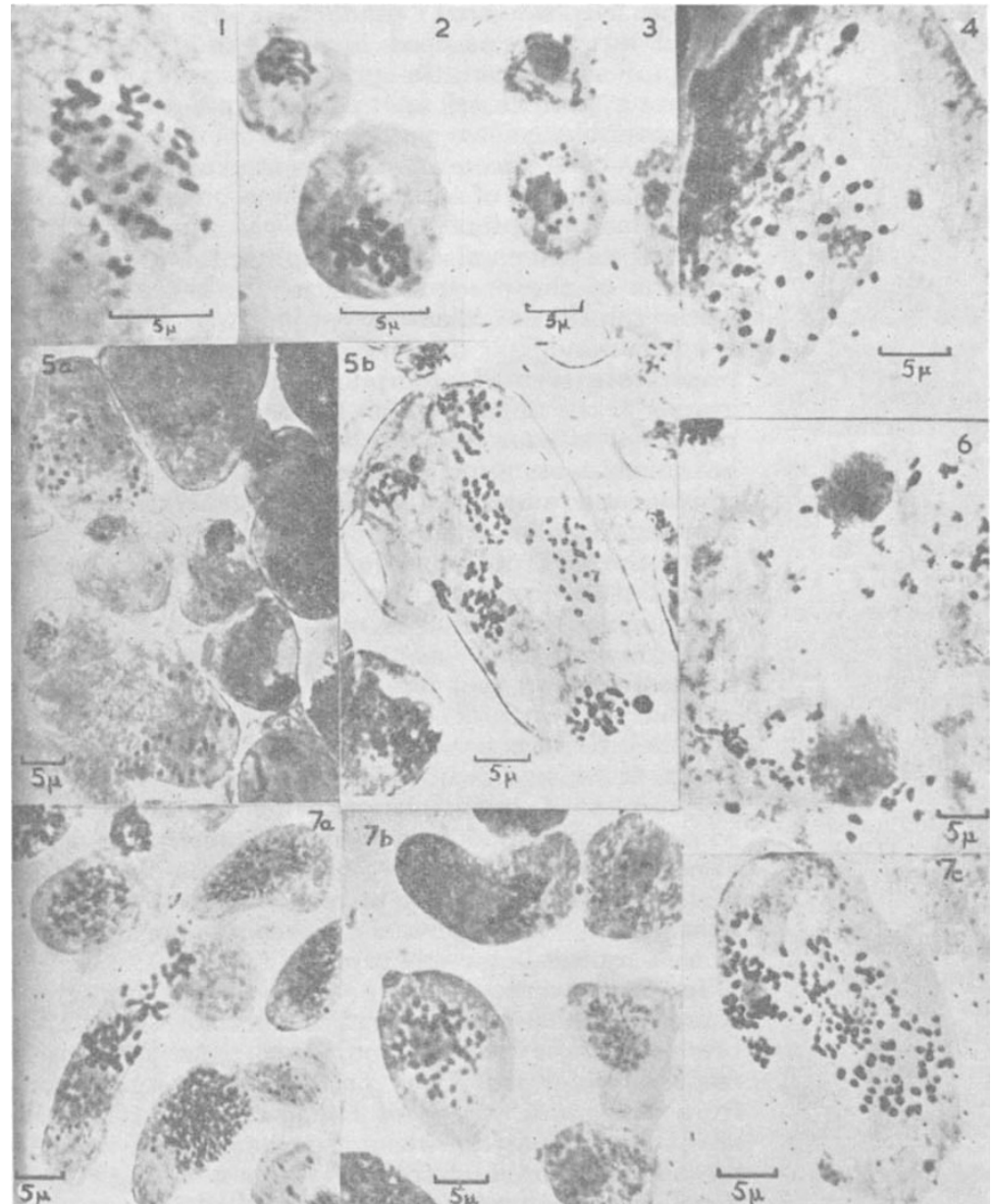

1, Cystoclonium purpureum (Huds.) Batt., diploid nucleus. 2, Rhodymenia palmata (L.) Grev., mitosis in cell of haploid thallus. 3, Polysiphonia nigrescens (Sm.) Grev., mitotic prophase in cell from antheridial tissue. 4, Polysiphonia elongata (Huds.) Harv,, division in a large cell from young tissues of haploid plant. 5a, Delesseria sanguinea (Hnds.) Kylin mimultaneous division of fronds on female thalli. $5 b$, Delesseria sanguinea (Huds.) Kylin confervoides (Huds.) Silva. ( $R$. subfusca (Woodw.) Ag.) interphase of meiosis in the tetrasporangium. 7a, Laurencia pinnatifida (Huds.) Lam. mitosis in haploid in the $7 b, L$. pinnatifida, mitosis in diploid plant. $7 c$, L. pinnatifida, simultaneous division in trinucleate cell of diploid plant

Laurencia pinnatifida and Rhodomela confervoides both have large sporangial nuclei which are easily studied at meiosis.

Department of Botany,

A. P. Austin

University College of Wales, Aberystwyth.

1 Rao, C. S. Prakasa, Nature, 172, 1197 (1953).

\& Parke, M., J. Mar. Biol. Assoc. U.K., 32, 497 (1953).

${ }^{3}$ Westbrook, M. A., Sond. Beih. Bot. Centrab., 53, Abt. A (1935).

“ Svedelius, N., Svensk. Bot. Tids., 6, Hf. 2 (1912).

\section{Apical Cell of Salt Marsh Fucoids}

IN 1950, S. Baker described the universal occurrence of a three-sided apical cell in a number of salt marsh fucoids ${ }^{1}$. Since no further publication on the anatomy of these plants has appeared, the following observations may be of interest.

On several occasions Fucus vesiculosus L. var. muscoides Cotton was collected from Clachan Sound, Argyllshire, where the plants form a tufted carpet stretching high up the shore together with Armeria maritima. An examination of these plants showed a series in development from those with a cylindrical thallus only $1 \mathrm{~cm}$. in length which branched profusely in a very irregu. lar manner to those $5 \mathrm{~cm}$. or more in length, with branching confined to one plane and with a flattened thallus showing some differentiation into midribs and wings. Sections through the apices of these plants showed a parallel series in development. The smallest plants had a very shallow apical groove at the base of which no distinct apical cell could be discerned. Slightly larger forms had the apical groove lined with hairs but still no differentiation of a distinct apical cell. The smallest of the forms which showed a tendency to flattening of the thallus had a distinct three-sided apical cell such as Baker describes ${ }^{1}$. Sometimes this was accompanied by apical hairs still lining the apical groove. Small attached plants nearby had a four-sided. apical cell, as is characteristic of the adult fucoid thallus. In fact, the apices of these plants of $F$. vesiculosus ecad muscoides demonstrated the successive stages through which the apex of the attached form of $F$. vesiculosus passes during its development from the sporeling to the adult thallus ${ }^{2}$.

The retention of the juvenile form of the apex is accompanied by little secondary activity of the various tissues. Very rarely was any evidence of secondary cortex seen, and few, if any, secondary hyphæ were found. Where the latter did occur, they often arose in tufts from a single cell of the innermost cortex and ramified in all directions through the thallus and not mainly towards the base of the plant as in attached forms. Occasionally hyphæ penetrated through the base of the plant, but these were not developed in sufficient numbers to interweave and form an attaching disk.

Baker and Bohling ${ }^{3}$ aseribed the origin of salt marsh fucoids to the production of adventitious branches from cast-up thalli, the branches separating with the decay of the parent plant. The anatomical structure of these plants of $F$. vesiculosus var. muscoides suggests the possibility that they originated from fertilized eggs which were cast high up the shore by spray and exceptional tides, into a zone unfavourable for normal growth and development. Under these conditions they survive and grow slowly, retaining the juvenile form and structure of the species and never reaching maturity and the formation of reproductive cells.

King's College,

Betty Moss

Newcastle upon Tyne.

${ }^{1}$ Baker, S. D., Nature, 165, 31 (1950).

2 Nienburg, W., Wiss. Meeresunters., Kiel, N.F., 21 (1931). Baker, S., and Bohling, M. H., J. Linn. Soc. Lond. (Bot.), 43
(1916). 